\title{
ヒト側頭骨病理研究補遺
}

\author{
佐 野 光 仁

\section{The Status of Human Temporal Bone Research in Osaka University Medical School}

\author{
Mitsuhito Sano \\ (Tondabayashi Hospital)
}

\begin{abstract}
We have investigated human temporal bones, especially in fetuses and newborn children to clarify the relation between the features of hearing impairment and temporal bone histopathological findings. About 300 temporal bone specimens were obtained from patients with 18 trisomy, $6 \mathrm{p}$ monosomy, $1 \mathrm{~g}+$ monosomy, Turner's syndrome, osteogenesis imperfecta, campomelic dysplasia, thanatophoric dysplasia, and mucopolysaccaridosis. Our method of preparation of temporal bone specimens is also described.
\end{abstract}

Key words: temporal bone, fetus, new born children, hearing impairment

はじめに

側頭骨病理の研究に電子顕微鏡が導入されて 以来, Ultramicroscopic な観察が動物実験だけ ではなく、ヒュウーマンのマテリアルについて も盛んに行われるようになってきた。しかし現 在においてもなお，側頭骨病理の研究に連続的 に側頭骨標本を作成し，メニエール病の本態と いわれている内リンパ水腫の発生の検討におい ては光学顕微鏡を用いた macroscopic な側頭 骨標本の研究がなお必要である。また蝸牛のコ ルチ器, 神経節細胞, 血管条の reconstruction 1)2)，コンピュータによる側頭骨の三次元構 築3)などには光学顕微鏡の側頭骨病理組織標本 が不可欠である.

また，大阪大学耳鼻咽喉科には1938年山川強 四郎先生が世界ではじめてィニエール病の側頭 骨標本4)を発表して以来伝統的に側頭骨の病理
研究が行われている.

しかしながらそれら側頭骨の研究も最近は動 物実験の分野でむしろ盛んで, 山川強四郎先生 以来依然と続いていたヒュウーマンの側頭骨研 究に関するものは少なくなってきた.

様々な疾患の病因, 病態を研究する基礎とし て臨床病理の重要性は言うまでもなく, ヒュ ウーマンの側頭骨に関する研究が少なくなって いる現状を息慮し, 再びヒュウーマンの側頭骨 の研究に着手した。成人の側頭骨を研究するこ とはもちろんのことであるが，剖検例が最近は 極度に減少している現状では成人の側頭骨の入 手はなかなか困難であるので，まず手始めに， 剖検例の多い胎児, 新生児の側頭骨に注目して, これらの標本を収集して，種々の疾患における 病理病態の解明に取り組むことにした。ここで は我々がいままでに経験した側頭骨の標本作成 
法よりはじめて，側頭骨採取の現況，今後の展 望について述べる。

\section{側頭骨標本の作製法}

側頭骨病理を研究するに当たり，一番重要な ことは，その形態的な変化がアーチィファクト 否かと言ら点である.アーチィファクトを惹起 する要因としてマテリアルを採取してから固定 までの時間（死後变化）, 固定液の種類, 固定 の時間, 脱灰液の種類, 脱灰の時間などが挙げ られる。

側頭骨標本の作製法として我々が 2,3 検討し た点を先ず述べることにする.

1 ）側頭骨標本の採取法5)677)

成人の側頭骨の採取法は従来よりょく行われ ているのは Schuknecht の側頭骨プラグが頭蓋 骨を開頭した場合には頭蓋底より側頭骨の錐体 部を円筒状くり貫くか，また開頭しない場合に は耳介より両耳を円筒状にくり貫く方法がとら れている。しかし胎児，新生児の側頭骨は柔ら かく，在胎日数の低い胎児では骨化が不十分で 側頭骨を採取するのは容易である，在胎日数 20 週未満の胎児であればメスで簡単に摘出できる. もら少し成長した胎児や新生児の場合には解剖 用のメスや八サミで簡単に摘出できる5)。側頭
骨摘出の際にはできるだけ外耳道，中耳腔の耳 小骨，外耳道，鼓膜もインタクトで採取できる ように注意している。

2 ）側頭骨の固定法8）（表 1 ）

側頭骨の固定には10\%のホルマリン液, Wittmaack 氏固定液 Heidenhein-SuSa 固定液 がしばしば用いられている，我々の教室では従 来より Wittmaack 氏固定液を用いている。そ れぞれの固定液に特徵があることが認められた。 特に言及したいことはホルマリン固定液と Plank-Rychlo 脱灰液は相性が悪いことである.

それぞれの固定液の特徵は，蝸牛において10 \%ホルマリン固定液では外リンパ腔である前庭 階，鼓室階については特に著変は認められなか った。しかし内リンパ腔である中央階にはへマ トキシリン・エオジンにて淡いピンク様に染ま る析出物の出現が認められた。 この物質は基底 回転，中央回転，頂回転の区別なく認められた。 また中耳腔側，側頭骨側の差はなかった。ライ スネル膜は 3 種類の固定法のなかでは一番張力 がかかっているよらにまっすぐであった。しか し基底回転の中耳側のライスネル膜だけが軽度 中央階の方へ陥凹する傾向が認められた．蓋膜 は膨化しており頂回転に行くほど程度は強く頂

表 1

\begin{tabular}{|c|c|c|c|}
\hline $\begin{array}{ll}\text { 部 位 } & \text { 固定法 } \\
\end{array}$ & 10\%ホルマリソ固定 & Wittmaack 氏固定 & Heidenhein-SuSa 固定 \\
\hline 中 央 階 & 析出物 $(+)$ & 析出物 $(-)$ & 析出物 $(-)$ \\
\hline ライスネル膜 & 伸展がよい & たるみ $(+)$ & たるみ $(+)$ \\
\hline 血 管 条 & 幅がうすい & 幅が少し厚い & 幅が少し厚い \\
\hline 蓋 膜 & 膨化，融解 & 融解していないが厚い & 収縮し，少しらすい \\
\hline コルチ器 & 全体の高さが低い & 全体の高さが高い & 全体の高さが高い \\
\hline 有毛細胞の染色度 & 淡 い & 中 間 & 濃 い \\
\hline ヘンゼン細胞 & & 細胞周囲に空胞形成（上回転） & \\
\hline 外ラセン溝上皮 & $\begin{array}{l}\text { 細胞質が融解 } \\
\text { (上方回転で著名) }\end{array}$ & $\begin{array}{l}\text { 上皮層が索状になり下層よりは } \\
\text { く離挙上回転に名) }\end{array}$ & 融解 (一) はく離 $(-)$ \\
\hline 内ラセン溝上皮 & $\begin{array}{l}\text { 細胞質が融解 } \\
\text { (上方回転で著名) }\end{array}$ & $\begin{array}{l}\text { 上皮層がはく離挙上 } \\
\quad(\text { 方回転に著名) }\end{array}$ & はく離 $(-)$ \\
\hline ラセン神経節 & 核が濃染 & & \\
\hline
\end{tabular}


回転では蓋膜の融解が認められた。コルチ器は 全体に高さが低く, 有毛細胞の染色性は弱く, 淡く染まる程度であった，外ラセン溝上皮，内 ラセン溝上皮ともに細胞質が融解してお拈り，こ の程度は上方回転に行くほど著名であった. 又 ラセン神経節細胞の核は一番強く濃染された。

Wittmaack 固定液では内リンパ腔, 外リン パ腔には10\%のホルマリンと異なって析出物は 認められなかった。しかしライスネル膜には膨 隆，陥凹のたるみが認められた，血管条は幅が 少し厚かった. 蓋膜はホルマリン固定と異なっ て融解してはいないが, 幅が厚い傾向が認めら れた.コルチ器では全体の高さが高く, 有毛細 胞の染色度は 3 種類の固定法では中間位であっ た. ヘンゼン細胞の周囲に，とくに上方回転に 空胞の形成が認められた. 外ラセン溝上皮, 内 ラセン溝上皮ともに索状になり基底膜より剝離 挙上していた。この程度は下方回転に行くほど 著名であった。

Heidenhein-SuSa 固定液では内リンパ腔, 外 リンパ腔ともに析出物を認めなかった．ライス ネル膜は全回転に軽度の陥凹が認められた。血 管条はホルマリン固定と異なり幅が少し厚かっ た。蓋膜は収縮し幅が薄かった。これは全回転 にわたり同程度に認められた。コルチ器は全体 の高さが高く有毛細胞の染色度は 3 種類の固定 法の中では一番濃染した. 外ラセン溝上皮, 内 ラセン溝上皮ともに融解, 剝離の現象は認めら れなかった。

前庭，半規管においては蝸牛と同様に $10 \%$ の ホルマリン液で内, 外リンパ腔に析出物を認め る以外，10\%のホルマリン液，Wittmaack 氏 固定液, Heidenhain-SuSa 固定液の 3 種類の固 定液による差は認めなかった。しかし半規管の 膨大部では全ての固定液で内リンパ腔が collapse になりやすい傾向を認めた.

3 ) 側頭骨の脱灰法

脱灰についてはしばしば用いられているもの としては EDTA が挙げられるが，我々の教室 では従来より Plank-Rychlo 脱灰液が用いられ
ている。しかしこの脱灰液は $10 \%$ のホルマリン 固定液とはどうも相性が悪く，前述したごとく コルチ器の変形やライスネル膜の変形などを生 じ易く, Plank-Rychlo 脱灰液には Wittmaack 固定液が相性が良いように思われる。ささらに脱 灰液については検討が必要と考光られる．現在 私たちは重金属による污染が問題となっている 事も考慮にいれ固定液と脱灰液について検討し ている.

4 ) 固定までの時間 (死後变化) ${ }^{9) 10)}$

さらに次に問題になるのはアーチィファクト を若起する要因としてマテリアルを採取してか ら固定までの時間（死後変化）である、マテリ アルを採取し固定までの時間の差（死後变化） による詳細な研究は山川, Fernandz によりな されているが，固定までの時間ができるだけ短 いことが当然のことであるが，我々のつたない 経験では夏であっても冷凍庫で貯蔵しておれば 24時間は評価できる標本の作成が，可能であろ 5 .

5 ) 標本の提示方法

最近はパーソナルコンピューターがいろいる な分野に用いられるよらになり，我々も簡単に 使用できるようになってきた。そこで側頭骨 データの整理だけにコンピューターを用いるの ではなく，セロイジンの連続切片を三次元的に 立体構築することにより複雑な構造をしている 側頭骨標本を三次元的にとらえることができる ようになった。我々のところではオリンパス製 の三次元構築プログラム“OZ”を用いて三次元 構築を行っている. 現在のところヒューマンの 側頭骨について三次元構築は行っていないが， 実験動物においてはその形態を調べる目的で行 っている. Sando, 高木 ${ }^{11) 12)}$, 原田ら ${ }^{3)}$, Green ${ }^{13)}$ の詳細な報告もなされているが，三次元構築す る際に，一番重要なことは基準線をいかに正確 につけるかといら点である，我々は針治療に使 用するできるだけ細い針をセロイジン包埋した 標本をミクロトームにセッティングしてその上 で台木にできる限り垂直にセロイジンに刺入す 
る事により行っている. 三次元構築の利点は複 雑な膜迷路の立体構造を今までであれば，連続 切片を光学顕微鏡で観察し, その立体構造を頭 の中でイメージしていたのであるがこれにはな かなか熟練を要していた．しかしながら三次元 立体構築ソフトを使用すると初心者でも複雑な 蝸牛, 三半規管, 前庭, 内リンパ管, 内リンパ 製等の構造, 位置的関係を即座にとらえること が可能となった。 また中耳腔の耳小骨の形態異 常, 顔面神経の走行異常, 頸動脈の走行異常等 を立体的に捉光, 手術の際に役にたつ可能性を 秘めている. 又学生に内耳の膜迷路, 中耳腔の 構造を理解さすことはなかなか困難なことであ るが, 三次元立体構築プログラムを用いれば, 教育上に多大な効果を期待できる. コンピュー タにデータをいれて括けばいつでも画像を引き 出せ, 又との画像を種々な角度より見ることが 出来る.さらにこれからは CT や MRI 画像の 三次元構築も容易に作成できるようになり，た とえば真珠腫性中耳炎の真珠種の広がりを術前 に的確に把握し，術中のトラブルを防げるもの と考えられる.

\section{側頭骨標本の収集の状態}

\section{1 ) 側頭骨の標本数}

大阪府立母子保健医療センタ一病理部の協力 のもとに1983年より新生児, 胎児の側頭骨を中 心に側頭骨の収集を始めている，母子医療セン ターでは年間約 100 例の剖検が行われているが, このうち開頭の許可が得られた $40 〜 50$ 例の症例 の側頭骨を一年間に得ている.今までに約 300 例近くの側頭骨を採取できた，標本には側頭骨 所見だけではなく, 解剖番号, 在胎日数, 性別, 剖検時の体重, 剖検時の診断名, 剖検所見, ま た後日判明した他の臓器の病理所見などを記載 し, コンピュータに登録し, データ整理を行う よらにしている. Sandoらが述べているょらな 側頭骨のデータ整理を参考にしている.

\section{2 ) 疾患の種類}

疾患種類は原因不明の胎内死亡，全身の骨系 統疾患, 他臓器の先天奇形 (心血管奇形など),
染色体異常, 先天性代謝異常（母体の代謝異常, たとえば母親の糖尿病), 感染症（母親のウイ ルス感染)，急性循環障害などが主な疾患であ る。しかしながら特に疾患を認めない胎児，新 生児でも側頭骨の発生（例えば側頭骨のリモデ リング等）を研究する手段として収集している.

3 ）我々の今までの報告

側頭骨病理の研究は欧米では Schuknecht, Sando, 五十嵐, Paparella などにより, 又日本 では石井, 大谷, 斎藤等により発育障害, 感染 症, 中毒, 循環障害, 代謝異常, 腫瘍（側頭骨 転移), メニエール病, 突発性難聴等について 詳細に述べられている. 奇しくも山川強四郎先 生自身が突発性難聴（ご本人はメニエール病と 思われていた）にかかられていたのであるが私 たちは先生の側頭骨の標本もまた報告する機会 を得た ${ }^{14)}$.

特に我々が興味を持っている先天性異常につ いては Sando らが精力的に検討している. れらの所見についてはほとんど我々の報告と一 致している．そこで我々は側頭骨の正常の発育 を含め，今までに主として

(1)全身性骨系統疾患

(2)染色体異常

(3)先天性奇形

(4)そのほか

について報告してきたがこれらの所見について まとめてみる。

(1)全身性骨系統疾患

全身性の骨系統疾患では Osteogenesis inperfecta congenita ${ }^{15) 16)}$, Thatophoric dwarfism $^{17)}$, Campomelic syndrome ${ }^{18)}$, Arythroglyposis ${ }^{19)}$ 等についてその迷路骨包の発育障害, 中耳腔の発育異常, 聴小骨形成異常, 骨迷路の 発育異常, 膜迷路の発育異常等について報告し てきた：その中で全身性に骨の形成異常があれ ば種々の形成異常が側頭骨に及んでくることが 判明した。私達はすぐに膜迷路の異常に注目し がちであるが，メニエール病に前庭導水管の形 成異常がレ線的に指摘されているごとく，迷路 
骨包特に middle layer, outer layer の形成異常 が膜迷路の形成異常, 特に内リンパ液の分泌, 吸収に関係するといわれている内リンパ管, 内 リンパ囊の長さ, 大ささの形成に重大な影響が あると考えられる。夢のよらなことではあるが これらの所見が染色体または遺伝子レベルで判 明すれば遺伝相談, 遺伝子診断の道が開かれ内 リンパ液の過剩分泌, 吸収障害が病因とされて いるメニエール病に遺伝子診断の道が開かれる のではなかららか。

(2)染色体異常

染色体異常の側頭骨についてもやはり現在ま でに私たちは 18 trisomy, Turner's syndrome, 6p partial monosomy, 1q+monosomy につい て報告しているが，ほかに 21 trisomy 等につ いての報告も散見される．これらの所見は今ま での報告と類似している。

18 trisomy では中耳組織では耳小骨のうち鐙 骨の奇形が認められた. 鐙骨の前脚, 後脚とも に細く, 後脚が底板の中心よりに付着し脚の付 着部位の異常が認められた. 底板自体も固着し ている．また鐙骨頭部に変形が見られた症例も あった．鐙骨付着部位は底板との固着はないも ののコルメラ状であった症例も認められた。

蝸牛では回転数が 1 回転半しかなく短蝸牛の 症例も認め, また全例を通じてラセン神経節細 胞は減少していたが, コルチ器, 血管条には異 常を認めなかった。さらに蝸牛軸の形成が悪く, 蝸牛が扁平の症例が多く, 蝸牛軸構造の一部が 欠損していたり, 中回転が左右融合し, 隔壁が 久損していた，そのほかの蝸牛の異常で正円空 の骨性閉鎖が認められた症例もあった。

前庭の異常としては球形翼, 卵形褧の拡大を 認めた。 また utricular endolyphatic valve が久 損していた。 さらに球形褧の一部には球形褧膜 が虚脱し, 感覚細胞上に異常な膜様物が形成し ており,この膜様物は球形褧膜が折れかえって 二重になっているようにも見られた.

また半規管の異常も目だち, 外側半規管, 前 半規管, 後半規管が太く短く, 位置も偏位して
おり, 膨大部稜では基底部に露胞の形成を認め た症例もあった。

Turner 症候群では鐙骨の形成不全が認めら れた。

6 partial monosomy は 6 番目の染色体長腕の 部分欠失である.両耳とも外耳道は閉鎖してお り, 耳垢腺組織を含む結合組織が充満しており, 中耳腔は両耳ともに狭く, 特に左側の方がより 狭かった，耳小骨は鐙骨，桘骨は確認できたが， 砧骨は判別できなかった。また鐙骨は固着はな いものの, 前脚, 後脚ともに細く形成不良であ った．蝸牛では頂回転と中回転の間隔壁が久損 しており, 回転数は約 2 回転しかなく、ラセン 神経節細胞も減少して拉り，ライスネル膜が虚 脱し，hair cell もほとんど欠如していたが，血 管条, 骨迷路には異常を認めなかった。球形裂, 卵形㐮は拡大して拉り, 内リンパ管も盲端に終 わっていたが, utriculo-endolymphatic valve は存在していた。また蝸牛軸の形成も悪く蝸牛 全体が扁平であった。

$1 \mathrm{q}^{+}$は一番目の染色体の長腕に過剩バンドが 認められたもので，その側頭骨標本は蝸牛小管 がやや拡大して括り, 蝸牛の回転数も 2 回転と 少な目であった。またラセン神経節細胞が減少 しており, 内リンパ管, 内リンパ権の拡大が認 められた。

これら染色体異常における特異的な側頭骨所 見すなわち, 外耳道, 鼓膜, 聴小骨, 骨迷路, 膜迷路の異常が云々する汪ど材料が揃ってはい ないが，もしも染色体異常特有の側頭骨病理所 見が判明すれば，やはりそれぞれの染色体異常 により若起される病態がより早期に判明し, 将 来の夢であろらが遺伝子治療も可能となるので はないだろらか。しかし何はともあれ染色体異 常の側頭骨標本の収集が重要な今後の課題とな るであろら。

(3)先天性奇形

さらに先天性奇形を伴った症例について研究 する目的は近年は ME 機器の発達や呼吸器, 循環器の集中治療法の確立などにより未熟児も 
成育できるようになっており，私達はこのよう な子供達の聴力発達に興味を持ち, 聴力障害の 有無を検討してきた。 その結果，聴力障害の発 生はただ単に出生時の体重が少ないかとか仮死 が強かったかといら新生児固有の問題のある子 供よりも心奇形や消化器奇形などの外科的な問 題を有する子供に発生率が高かったことを報告 しているが，この事実にもとづいてこれらの異 常を形態的にとら兄よと努力している．その 中でもしも形態的異常を早期に発見し，早期に 育成，治療が可能であればこれらの障害をもっ て生まれた子供達に少なからずの福音とならう． 又これらの子供達はいずれは外科的な処置を行 らであろらが，外科的処置を施した際にもしも 術後より難聴の発生に気がついた際にはそれが 子供達本来の障害か, あるいは術後に使用した 抗生剂等の影響か否かの判断材料にもなろらと 考えられる. 最近は治療の過程で医療過誤も問 題がしばしば発生するのでこの点から考えても 我々医師サイドでは重要な問題であろう。

(4)その他

その他正常に生まれたがなんらかのアクシデ ントで死亡した側頭骨を収集していると内耳の 形態を研究する上で役立つこともある．最近は CT, MRI などが盛んに内耳疾患の研究に用い られるようになってきたが，膜迷路の MRI に てとらえる努力が行われ，我々もとの一翼を担 っている20). 現在のところ MRI ではライスネ ル膜は判定できないが近い将来可能であろう。 これが現実になればメニエール病の画像診断も 夢ではなくなるであろう。

\section{今後の課題}

側頭骨病理研究の今後の課題として私たちが最 も重要と考光ていること点は側頭骨切片作成の 時間の短縮である. 現在沉用されている包埋材 であるセロイジンを使うと切片ができるまで 4 〜 6 カ月かかってしまい, 種々の研究の早さと 比較するとその速度は遅々たるものである．何 とかもっと早く連続切片ができる包埋材の開発 が望まれる。ささらもら一つは側頭骨切片作成
の技術者の養成である，幸い我々の所では熟練 した技術者に恵まれているが，その待遇の面か ら考学るともら少しの改善を考える必要がある 5 .

ともかく側頭骨の臨床病理の研究は臨床だけ ではなく実験をも加えた形で更なる発展を期待 しょう。

稿を終えるにあたり，唄頭骨標本の採取に多大の ご尽力をいただいた大阪府立母子保健医療センター 病理部 中山雅弘先生飞深謝いたします。

\section{参考文献}

1) Guild SR : A graphic reconstruction method for the study of the organ Corti. Anat Rec $22: 141 \sim 157,1921$.

2) Schuknecht HF : Techniques for study of cochlear function and pathology in experimental animals. Development of the anatomical frequency scale for the cat. Arch Otolaryngol $58: 377 \sim 397,1953$.

3) T Harada, S Ishii and N Tayama: Threedimensional reconstruction of the temporal bone from histologic sections. Arch Otolaryngol Head Neck Surg $114:$ 1139 1142, 1988.

4）山川強四郎：メニェール氏病 7 呈セシ患者の聴 器. 日耳鼻 $44: 2310 \sim 2112,1938$.

5）佐野光仁，中山雅弘：側頭骨病理標本作成法. 日本医事新報，3396：150，1989.

6）側頭骨研究会編：ヒ上側頭骨病理組織標本作成 法の手引. 1973.

7) Schuknecht HF : Pathology of the ear. Harvard University Press, 1974.

8) SH Mygind : Experimental histological studies on the labyrinth; the endolymphatic compression (Wittmaack's hypotenic degeneration). Acta Otolarngol $33: 86 \sim 116,1945$.

9) 山川強四郎：聴器の死後変化. 耳鼻咽喉科最近 の進歩. 353 361頁. 医茵薬出版社, 1956.

10) Fernandez $C:$ Postmortem changes in the vestibular and cochlear receptors (Guinea pig). Arch Otolaryng $64:$ 460 487, 1958.

11) Takagi A and Sando I : Computer-aided three- 
dimensional reconstruction; a method of measuring temporal bone sturctures including the length of the cochlea. Ann Otol Rhinol Laryngol $98: 515 \sim 522,1989$.

12) Takagi A, Sando I and Takahashi H : Computer-aided three-dimensional reconstruction and measurement of semicircular canals and their cristae in man. Acta Otolaryngol 107 : 362 369, 1989.

13) Green JD, Marison MS, Erickson BJ, et al : Three dimensional reconstruction of the temporalbone. Laryngoscope $100: 1 \sim 4,1990$.

14）佐野光仁, 阪上雅史, 原田保, 他: 山川強四 郎名誉教授の側頭骨病理所見. Equilibrium Res $45: 302 \sim 305,1986$.

15）佐野光仁, 松永 亭, 須沢八千代, 他: Osteogenesis imperfecta の側頭骨病理. 耳鼻臨床耳 科 $13: 474 \sim 475,1986$.

16）佐野光仁, 阪上雅史, 原田保, 他: Osteo- genesis imperfecta の側頭骨病理所見. Ear Res Jpn $18: 436 \sim 437,1987$.

17）佐野光仁, 阪上雅史, 原田 保, 他: THANATOPHORIC DYSPLASIA の側頭骨病理所見. 臨床耳科 $15: 5 \sim 11,1988$.

18）B Kalubi, 佐野光仁, 阪上雅史, 他 : The temporal bone histopathological findings in the campomelic syndrome. Ear Res Jpn $19: 212$ $\sim 215,1988$.

19）佐古雅子, 佐野光仁, 原田 保, 他: Arythroglyposis の側頭骨病理所見. Ear Res Jpn 20 : 281 282, 1989.

20）肥塚 泉, 佐野光仁, 久保 武, 他: MRI に よる側頭骨標本を用いた内耳の撮影。耳鼻臨床 $83: 549 \sim 555,1990$.

$$
\left(\begin{array}{l}
\text { 別刷請求先 : 佐野光仁 } \\
\text { 厂5 } 84 \text { 富田林市向陽台1-3-36 } \\
\text { 富田林病院耳鼻咽喉科 }
\end{array}\right)
$$

